\title{
Low diversity of foot-and-mouth disease serotype C virus in Kenya: evidence for probable vaccine strain re-introductions in the field
}

\author{
Sangula, Abraham; Siegismund, Hans; Belsham, Graham; Balinda, Sheila; Masembe, Charles; \\ Muwanika, Vincent
}

\author{
Published in: \\ Epidemiology and Infection
}

Link to article, DOI:

$10.1017 /$ S0950268810000580

Publication date:

2011

Document Version

Publisher's PDF, also known as Version of record

Link back to DTU Orbit

Citation (APA):

Sangula, A., Siegismund, H., Belsham, G., Balinda, S., Masembe, C., \& Muwanika, V. (2011). Low diversity of foot-and-mouth disease serotype $\mathrm{C}$ virus in Kenya: evidence for probable vaccine strain re-introductions in the field. Epidemiology and Infection, 139(2), 189-196. https://doi.org/10.1017/S0950268810000580

\section{General rights}

Copyright and moral rights for the publications made accessible in the public portal are retained by the authors and/or other copyright owners and it is a condition of accessing publications that users recognise and abide by the legal requirements associated with these rights.

- Users may download and print one copy of any publication from the public portal for the purpose of private study or research.

- You may not further distribute the material or use it for any profit-making activity or commercial gain

- You may freely distribute the URL identifying the publication in the public portal 


\title{
Low diversity of foot-and-mouth disease serotype $\mathbf{C}$ virus in Kenya: evidence for probable vaccine strain re-introductions in the field
}

\author{
A. K. SANGULA ${ }^{1,2 *}$, H. R. SIEGISMUND ${ }^{3}$, G. J. BELSHAM ${ }^{4}$, S. N. BALINDA ${ }^{1}$, \\ C. MASEMBE${ }^{1}$ AND V. B. MUWANIKA ${ }^{1}$ \\ ${ }^{1}$ Makerere University, Institute of Environment and Natural Resources, Molecular Biology Laboratory, \\ Kampala, Uganda \\ ${ }^{2}$ Foot-and-Mouth Disease Laboratory, Embakasi, Nairobi, Kenya \\ ${ }^{3}$ Department of Biology, Ole Maaløes Vej 5, Copenhagen ØN, Denmark \\ ${ }^{4}$ National Veterinary Institute, Technical University of Denmark, Lindholm, Kalvehave, Denmark
}

(Accepted 17 February 2010; first published online 25 March 2010)

\section{SUMMARY}

Most viruses are maintained by complex processes of evolution that enable them to survive but also complicate efforts to achieve their control. In this paper, we study patterns of evolution in foot-and-mouth disease (FMD) serotype $\mathrm{C}$ virus isolates from Kenya, one of the few places in the world where serotype $\mathrm{C}$ has been endemic and is suspected to remain. The nucleotide sequences encoding the capsid protein VP1 from eight isolates collected between 1967 and 2004 were analysed for patterns of sequence divergence and evolution. Very low nucleotide diversity $(\pi=0 \cdot 0025)$ and remarkably little change (only five segregating sites and three amino-acid changes) were observed in these isolates collected over a period of almost 40 years. We interpret these results as being suggestive of re-introductions of the vaccine strain into the field. The implications of these results for the maintenance of serotype C FMD virus and the use of vaccination as a control measure in Kenya are discussed.

Key words: FMDV serotype C, Kenya, sequence divergence, vaccine strain.

\section{INTRODUCTION}

Foot-and-mouth disease virus (FMDV) is an Aphthovirus within the family Picornaviridae. It causes a highly contagious disease (FMD) in cloven-hoofed animals (domestic and wild) which is the most significant constraint to international trade in livestock and livestock products today [1]. The genome of FMDV is a positive-sense RNA of about $8.5 \mathrm{~kb}$ which encodes a polyprotein that is processed to the

\footnotetext{
* Author for correspondence: Dr A. K. Sangula, Makerere University Institute of Environment and Natural Resources, Molecular Biology Laboratory, P.O. Box 7298, Kampala, Uganda. (Email: aksangula@muienr.mak.ac.ug or aksangula@gmail.com)
}

four structural proteins (VP1-VP4) of the virus capsid (only VP1-VP3 are surface exposed) plus several nonstructural proteins required for virus replication and protein processing [2]. FMDV occurs in seven immunologically distinct serotypes namely $\mathrm{O}, \mathrm{A}, \mathrm{C}$, Southern African Territories (SAT) 1-3, and Asia 1. The seven serotypes have different global distributions with type $\mathrm{C}$ belonging to the Euro-Asiatic serotypes which include $\mathrm{O}, \mathrm{A}$ and Asia 1. Type C FMDV was first described by Waldmann \& Trautwein [3] and has since had a limited distribution. It has been recorded in Europe, South America, East Africa, North Africa, Angola and Southern Asia [4]. At present, the last reported cases of type C were in 2004 


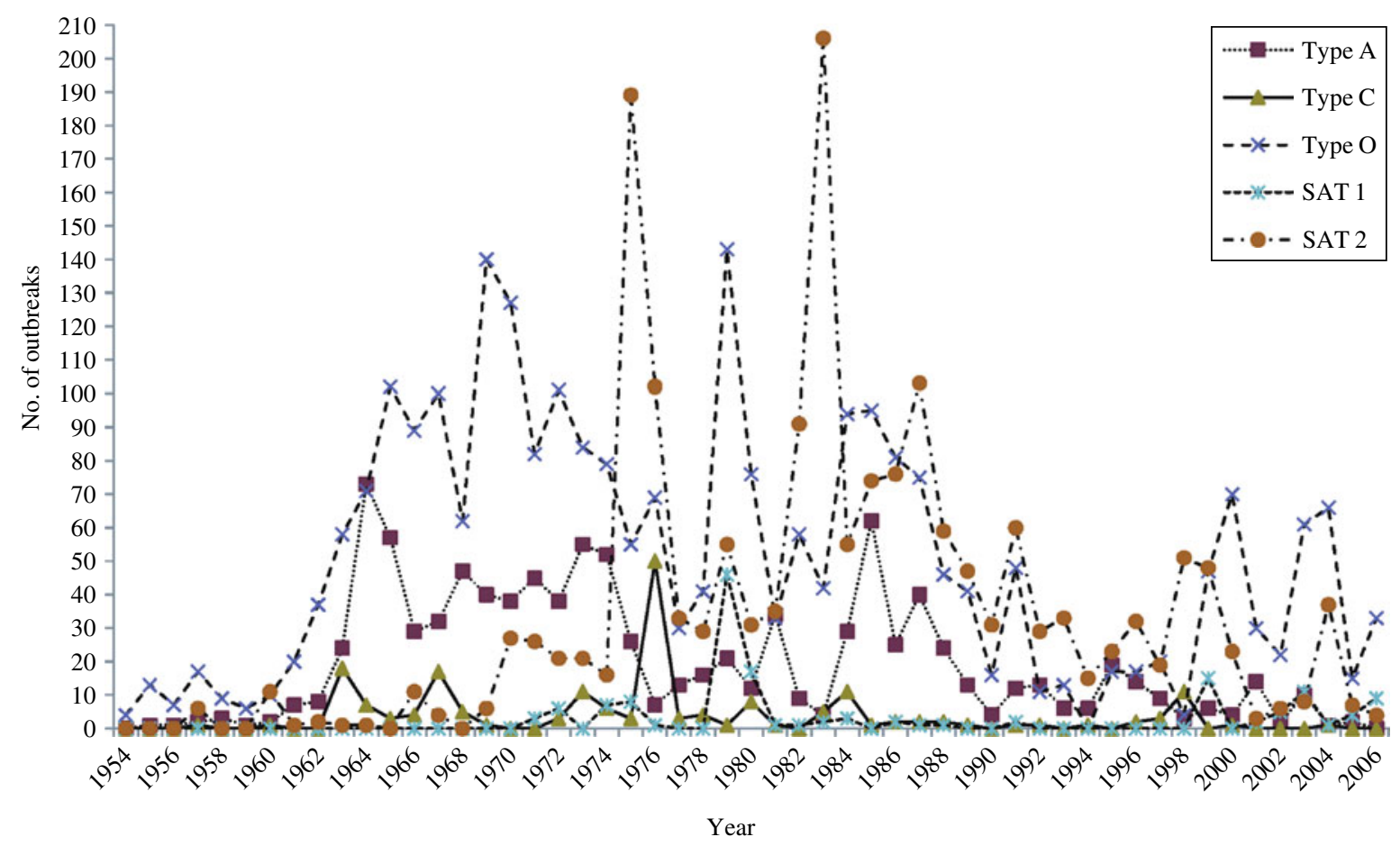

Fig. 1. Frequency of recorded outbreaks of foot-and-mouth disease by serotype in Kenya (1954-2006).

in Brazil and Kenya [5]. In the wider East African region, type $\mathrm{C}$ was last reported in Uganda in the 1970s and Ethiopia in $1983[4,5]$.

Records of serotype C outbreaks of FMD in Kenya date back to 1957 with almost yearly occurrences in some districts across the country which peaked in the mid 1970s (Department of Veterinary Services, Kenya). However, from the mid-1980s, the distribution of these outbreaks has been geographically limited to two districts in the central Rift Valley (Baringo and Koibatek). The numbers of recorded outbreaks of FMD, by serotype, for each year in Kenya from 1954 to 2006 are illustrated in Figure 1. Most of the reported outbreaks have been in cattle with serotypes C and SAT 1 being the least prevalent while serotypes $\mathrm{O}$ and SAT 2 were the most common. In Kenya, only one type $\mathrm{C}$ vaccine strain (termed $\mathrm{K} 267 / 67$ and originally isolated from Laikipia district) produced by the Kenya Veterinary Vaccines Production Institute (KEVEVAPI) has been used to contain outbreaks of type C since the 1970s (Department of Veterinary Services, Kenya records). KEVEVAPI also produces vaccines for serotypes $\mathrm{O}$ (K77/78), A (K5/80, K35/80), SAT 1 (T155/71) and SAT 2 (K52/84).

Molecular epidemiology studies are a helpful guide for understanding disease dynamics and for vaccine development. Most viruses are maintained by complex processes of evolution that enable them to survive but this also complicates efforts aimed at achieving disease control. High levels of genetic sequence diversity such as that reported for SAT 2 in Africa complicates diagnosis and vaccination since the development of suitable serotype-specific primers and vaccine strains is difficult [6]. Molecular characterization of FMDV field strains is useful in tracing the origin of outbreaks and can aid in identifying possible vaccine-related outbreaks which are genetically very close to vaccine strains $[4,7]$.

Kenya is one of the few remaining suspected habitats of type C FMDV globally and efforts towards progressive control of FMD will benefit from establishing the current status of this serotype in this country. Understanding the evolutionary forces shaping the epidemiology of this intermittently occurring serotype is thus desirable. This information is also useful for decisions on control strategies and in particular the use of vaccination in endemic settings like Kenya.

This study was undertaken to establish patterns of evolution of type C from FMD outbreaks that occurred during the period (1967-2004) using isolates that had been stored at the Embakasi FMD laboratory. The VP1-coding region was used for sequence analysis as it is one of the structural proteins forming the virus capsid and contains important antigenic sites 


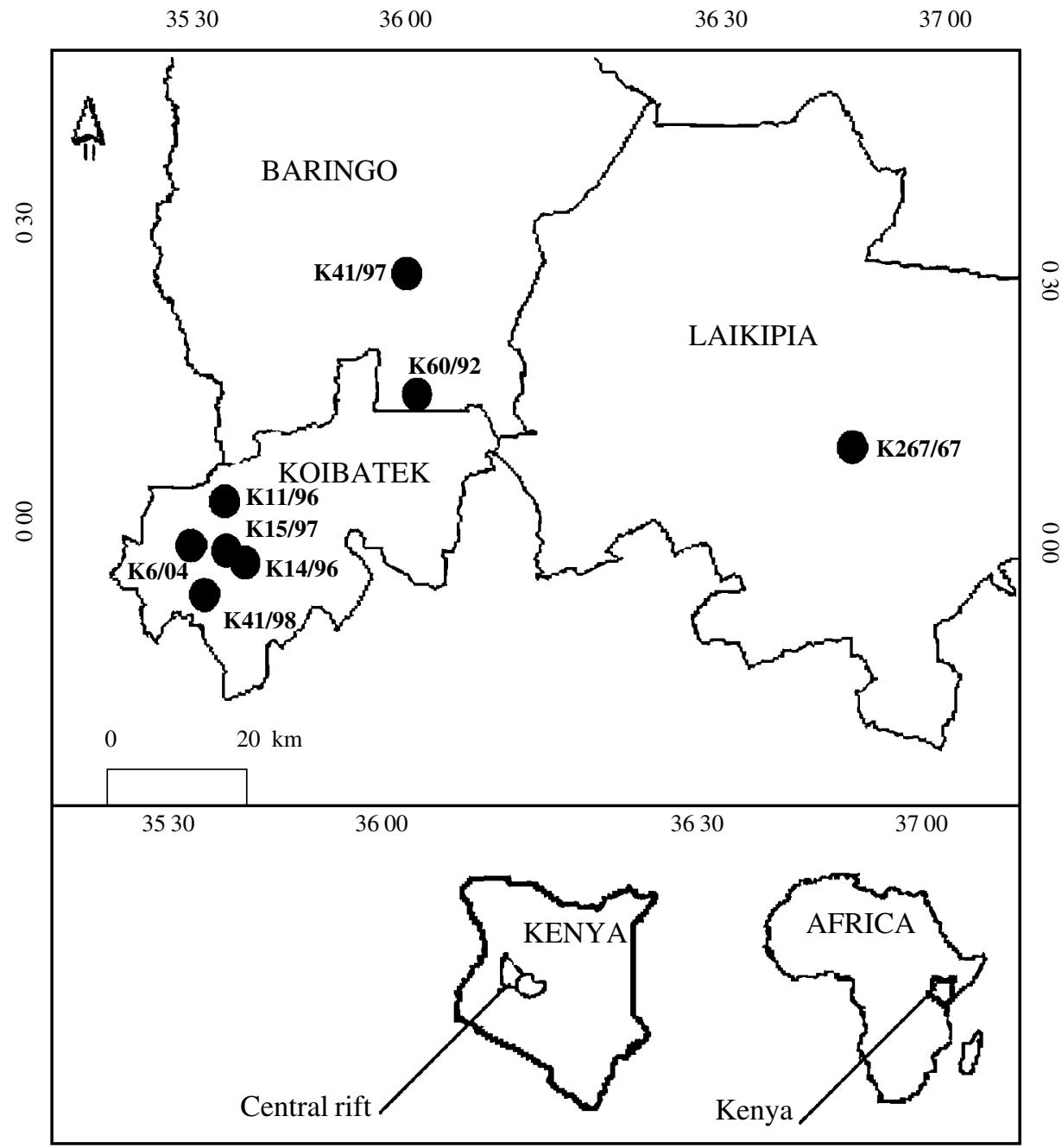

Fig. 2. Map of Kenya indicating the geographic origin of the type $\mathrm{C}$ foot-and-mouth disease virus isolates included in this study. $\bullet$, Sample site; —_, district.

plus the integrin receptor binding motif and is likely to reflect the evolutionary dynamics of the virus population. It has also been widely analysed previously and thus much information is available for most serotypes.

\section{METHODS}

\section{Virus isolates}

Eight type $\mathrm{C}$ virus isolates were obtained from the Embakasi FMD laboratory, Nairobi, for this study. This laboratory is a repository of all FMD sample materials collected in Kenya. The type $\mathrm{C}$ samples had been collected over a period of almost 40 years (1967-2004). Due to the long-term storage at $-70{ }^{\circ} \mathrm{C}$, some of the viruses were passaged at least once in BHK monolayer cells, one at a time, before RNA extraction. Attempts at passaging more of the type C samples from the bank in BHK cells were unsuccessful, possibly due to deterioration as a result of unreliable power supplies. All of the eight virus isolates were collected from outbreaks that occurred in the districts of the central part of the Rift Valley province of Kenya as shown in Figure 2. The details of the isolates are shown in Table 1. Nine other published type C FMDV VP1-coding sequences representing the main topotypes were included for phylogenetic comparisons.

\section{Viral RNA extraction, cDNA synthesis and amplification}

Total RNA was extracted using the QIAamp ${ }^{\circledR}$ Viral RNA Mini kit (Qiagen, Germany) according to the manufacturer's instructions. cDNA synthesis was 
Table 1. List of the type C viruses included in this study of which eight sequences derived from Kenyan viruses were generated in this work while nine were sourced from published reports

\begin{tabular}{lllll}
\hline \hline Lab. ref no. & $\begin{array}{l}\text { Year of } \\
\text { isolation }\end{array}$ & $\begin{array}{l}\text { District/ } \\
\text { country }\end{array}$ & $\begin{array}{l}\text { Accession } \\
\text { no. }\end{array}$ & Topotype \\
\hline $\begin{array}{l}\text { ETH/1/71 } \\
\text { USSR/Tadjn/67 }\end{array}$ & 1971 & Ethiopia & FJ798151 & Africa \\
IND/42/77 & 1967 & Tadjikstan & WRL & Asia \\
BRA/Resnd/55 & 1955 & India & WRL & Asia \\
SPA/StPa/70 & 1970 & Brazil & M90381 & Euro-SA \\
BRA/Indl/71 & 1971 & Brazil & AJ133357 & Euro-SA \\
PHI/7/84 & 1984 & Philippines & WRL & Euro-SA \\
GER/CGC/26 & 1926 & Germany & EU553893 & $?$ \\
UK/149/34 & 1934 & UK & AY593810 & $?$ \\
K60/92 & 1992 & Baringo & GU451110 & Africa \\
K15/97 & 1997 & Koibatek & GU451111 & Africa \\
K267/67 & 1967 & Laikipia & GU451109 & Africa \\
K14/96 & 1996 & Koibatek & GU451116 & Africa \\
K41/97 & 1997 & Baringo & GU451112 & Africa \\
K6/04 & 2004 & Koibatek & GU451113 & Africa \\
K41/98 & 1998 & Koibatek & GU451114 & Africa \\
K11/96 & 1996 & Koibatek & GU451115 & Africa \\
\hline \hline
\end{tabular}

$\mathrm{WRL}=$ from World reference laboratory sequence data website (http://www. wrlfmd.org/fmd_genotyping/prototypes.htm).

?, Not assigned.

performed using Ready-To-Go ${ }^{\mathrm{TM}}$ You-Prime FirstStrand Beads (GE Healthcare Life Sciences, Sweden) with random hexamer primers $\left(\mathrm{pdN}_{6}\right)$. PCR amplification of the VP1-coding region was achieved using forward primers; C-1C $\mathrm{C}_{536}$ (5'-TACAGGGATGGGTCTGTGTGTACC-3') or C-1C (16 $_{616}$ (5'-AAAGACTTTGAGCTCCGGCTACC-3') with the reverse primer FMD-2B F $_{58}$ (5'-GACATGTCCTCCTGCATCTG-3') [8] yielding products of $\sim 880 \mathrm{bp}$ and $\sim 800 \mathrm{bp}$, respectively. Five microlitres of template cDNA were added to $45 \mu \mathrm{l}$ PCR reaction mixture containing $0 \cdot 2 \mu \mathrm{M}$ primers, $200 \mu \mathrm{M}$ of each dNTP, $1.5 \mathrm{~mm} \mathrm{MgCl}_{2}$ and $1 \mathrm{U}$ of Amplitaq gold DNA polymerase (Applied Biosystems, UK). Amplifications were performed using an Eppendorf Mastercycler (Eppendorf, Germany) incorporating a touchdown profile as follows: enzyme activation at $95^{\circ} \mathrm{C}$ for 5 min, 7 cycles of $95^{\circ} \mathrm{C}$ for $15 \mathrm{~s}$, touchdown of $57{ }^{\circ} \mathrm{C}$ to $51{ }^{\circ} \mathrm{C}$ (with a decrease of $1{ }^{\circ} \mathrm{C}$ in the subsequent cycle) for $1 \min 30 \mathrm{~s}, 72^{\circ} \mathrm{C}$ for $1 \min 20 \mathrm{~s}$. This was followed by a standard PCR of 30 cycles at $95^{\circ} \mathrm{C}$ for $15 \mathrm{~s}, 50{ }^{\circ} \mathrm{C}$ for $1 \mathrm{~min} 30 \mathrm{~s}, 72^{\circ} \mathrm{C}$ for $1 \mathrm{~min}$ $20 \mathrm{~s}$ and a final extension step at $72{ }^{\circ} \mathrm{C}$ for $20 \mathrm{~min}$. PCR products were examined by electrophoresis on $2 \%$ agarose gel using ethidium bromide staining and a molecular-weight marker $\Phi X 174-R F$ DNA (Amersham, Biosciences). The expected products were purified using the QIAquick PCR purification kit (Qiagen). Both strands of the amplicons were cyclesequenced using BigDye technology on an ABI 3700 automated DNA sequencer (Applied Biosystems) employing the forward primers used in the PCRs and FMD-2A $\mathrm{A}_{34}$ (5'-GAAGGGCCCAGGGTTGGACTC-3') [8] within the $2 \mathrm{~A}$ region as the reverse primer.

\section{Sequence analysis}

The entire VP1-coding regions (630 nt) from the eight Kenyan FMDV type $\mathrm{C}$ sequences generated in this study and nine other reference sequences (Table 1) were aligned using the software programs Sequencher 4.8 (Gene Codes Corporation, USA) and Geneious v. 4.6 [9]. The model of evolution that best fits the data was selected using Akaike's Information Criteria and hierarchical likelihood ratio tests in MrModeltest2.2 [10] as implemented in PAUP $* 4 \mathrm{~b} 10$ [11] resulting in the selection of the HKY evolutionary model [12] with gamma-distributed rate variation across sites and a proportion of invariable sites $(\mathrm{HKY}+\mathrm{I}+\mathrm{G})$ as the preferred model. 


\begin{tabular}{|c|c|c|c|c|c|c|c|c|c|c|c|}
\hline & $\mathrm{T} / \mathrm{G} / \mathrm{A}$ & $Q$ & $\mathbf{R}$ & $\mathbf{R}$ & $G / S$ & $\mathrm{~L} / \mathrm{M} / \mathrm{P}$ & & & $\mathrm{T} / \mathrm{G}$ & $Q$ & \\
\hline & $\mathrm{s}$ & $\mathrm{H}$ & G & P & $\mathrm{R}$ & G & D & $\mathrm{s}$ & A & $\mathrm{H}$ & L \\
\hline & 333 & 333 & 333 & 333 & 444 & 444 & 444 & 444 & 444 & 444 & 444 \\
\hline & 000 & 222 & 333 & 333 & 333 & 333 & 333 & 344 & 444 & 444 & 445 \\
\hline & 789 & 567 & 123 & 456 & 012 & 345 & 678 & 901 & 234 & 567 & 890 \\
\hline $\mathrm{ER} / \mathrm{CGC} / 26$ & AGC & CAC & GGG & CCG & AGA & GGG & GAT & TCG & GCT & CAC & CTG \\
\hline UK/149/34 & $\ldots$ & $\ldots$ & $\ldots$ & $\ldots$ & G. . & $\ldots$ & $\ldots$ & CT. & A.. & $\ldots$ & $\ldots$ \\
\hline BRA/Res/55 & . C. & $\ldots$ & $\ldots A$ & $\ldots$ & $\ldots$ & $\ldots$ A & $\ldots$ & CT. & $\ldots \mathrm{C}$ & $\ldots \mathrm{T}$ & T.. \\
\hline USSR/Ta/67 & G.. & $\ldots$ & $\ldots \mathrm{A}$ & $\ldots$ & $\ldots \mathrm{T}$ & $\ldots$ & $\ldots \mathrm{C}$ & AT. & $\ldots$ & $\ldots$ & T. . \\
\hline $\mathrm{SPA} / \mathrm{StP} / 70$ & .C. & $\cdots$ & $\ldots \mathrm{C}$ & $\ldots$ & --- & $\ldots$ & $\ldots$ & .T. & $\cdots$ & $\ldots$ & $\ldots A$ \\
\hline d/71 & GC. & $\cdots$ & $\ldots A$ & $\cdots$ & $\ldots G$ & $\ldots A$ & $\ldots$ & CTA & $\ldots \mathrm{C}$ & $\ldots$ & T. . \\
\hline IND/42/77 & $\ldots$ & $\ldots$ & $\ldots \mathrm{A}$ & $\ldots$ & $\ldots$ & $\cdots$ & $\ldots \mathrm{C}$ & AT. & $\ldots$ & $\ldots \mathrm{T}$ & T. . \\
\hline $\mathrm{HI} / 7 / 84$ & .C. & $\ldots$ & $\ldots \mathrm{A}$ & $\ldots$ & G. . & $\ldots \mathrm{A}$ & $\ldots$ & .T. & $\ldots \mathrm{C}$ & $\ldots G$ & $\ldots$ \\
\hline$/ 71$ & $\cdots$ & $\cdots$ & $\ldots \mathrm{A}$ & $\ldots$ & $\cdots$ & $\ldots \mathrm{A}$ & $\ldots$ & C.. &.$G$. & $\ldots A$ & $\ldots$ \\
\hline $267 / 67$ & $\cdots$ & $\cdots$ & $\ldots A$ & $\ldots$ & $\ldots$ & $\ldots A$ & $\ldots \mathrm{C}$ & CT. &. $\mathrm{G}$. & $\ldots A$ & $\ldots$ \\
\hline $60 /$ & $\ldots$ & $\ldots$ & A.A & $\ldots$ & $\ldots$ & $\ldots A$ & $\ldots \mathrm{C}$ & CT. &.$G$. & $\ldots A$ & $\ldots$ \\
\hline $\mathrm{K} 11 / 96$ & $\ldots$ & $\ldots$ & A.A & $\ldots$ & $\ldots$ & $\ldots A$ & $\ldots C$ & CT. &. $\mathrm{G}$. & $\ldots \mathrm{A}$ & $\ldots$ \\
\hline K14/96 & $\ldots$ & $\ldots$ & $\ldots \mathrm{A}$ & $\ldots$ & $\ldots$ & $\ldots \mathrm{A}$ & $\ldots \mathrm{C}$ & CT. &. $\mathrm{G}$. & $\ldots \mathrm{A}$ & $\ldots$ \\
\hline K15/97 & $\ldots \mathrm{T}$ & $\ldots A$ & $\ldots A$ &.$G$. & $\ldots$ & $\cdots$ & $\ldots \mathrm{C}$ & CT. &. $\mathrm{G}$. & $\ldots A$ & $\ldots$ \\
\hline K41/97 & $\cdots$ & $\ldots$ & A. A & $\ldots$ & $\ldots$ & $\ldots A$ & $\ldots \mathrm{C}$ & CT. &. $\mathrm{G}$. & $\ldots A$ & $\cdots$ \\
\hline $\mathrm{K} 41 / 98$ & $\cdots$ & $\cdots$ & A. A & $\cdots$ & $\cdots$ & $\ldots \mathrm{A}$ & $\ldots \mathrm{C}$ & CT. &.$G$. & $\ldots A$ & $\cdots$ \\
\hline $6 / 04$ & $\ldots$ & $\ldots$ & A.A & $\cdots$ & $\cdots$ & $\ldots A$ & $\ldots \mathrm{C}$ & CT. &.$G$. & $\ldots A$ & $\ldots$ \\
\hline a position & 103 & 109 & 111 & 112 & 144 & 145 & 146 & 147 & 148 & 149 & 150 \\
\hline
\end{tabular}

Fig. 3. VP1 coding region and amino-acid sequence comparison between the serotype $\mathrm{C}$ sequences analysed in this study. Only variable sites indicating changes in the Kenyan sequences are shown with nucleotide and amino-acid positions marked above and below the sequences, respectively. Variant amino acids (aa) are indicated in bold. '.' Indicates a nucleotide site identical to that of the sequence GER/CGC/26 (Germany, 1926) and '-' denotes a missing nucleotide.

\section{Sequence characteristics}

The level of nucleotide sequence divergence was inferred using DnaSP v5 [13] to determine values of nucleotide diversity, pi $(\pi),[14]$ and the number of segregating sites. The amino-acid substitutions predicted from the sequences were identified using MEGA4 [15].

\section{Phylogenetic relationships}

Phylogenetic relationships between the type $\mathrm{C}$ virus isolates were determined using MrBayes [16] assuming an $\mathrm{HKY}+\mathrm{I}+\mathrm{G}$ model. The Markov Chain Monte Carlo search was run with three chains for 500000 generations; with trees being sampled every 100 generations (the first 500 trees were discarded as 'burn-in').

\section{RESULTS}

\section{Sequence characteristics}

A very low level of nucleotide diversity (values of $\pi=0 \cdot 0025$ ) was observed in the eight Kenyan FMDV type C VP1-coding sequences. There were only five segregating sites at nucleotide positions 309, 327, 331, 335 and 435 . These substitutions encoded only three amino-acid changes within the VP1 protein (at residues
$109,111,112)$ resulting from the non-synonymous nucleotide changes at positions 327, 331 and 335 in the Kenyan virus isolates (Fig. 3). While the other Kenyan type $\mathrm{C}$ virus isolates were invariant at aminoacid residues 109 and 112, the isolate K15/97 had two substitutions [glutamine $(\mathrm{Q})$ and arginine $(\mathrm{R})$ in place of histidine (H109) and proline (P112), respectively]. However, the K15/97 isolate, together with isolates K267/67 and K14/96, had a glycine (G) residue at position 111, like the reference topotypes, while the other Kenyan virus isolates had an arginine (R). It should be noted that the 'RGD' motif (residues 144-146), required for binding to the integrin receptor $[17,18]$, was completely conserved in the Kenyan serotype $\mathrm{C}$ virus isolates.

\section{Phylogenetic relationships}

The Kenyan FMDV type $\mathrm{C}$ virus isolates are very closely related to each other within the African topotype (Fig. 4). They belong to a single clade on the phylogenetic tree. The vaccine strain K267/67 is identical to K14/96 in this region while the others (K11/96, K41/97, K41/98, K6/04) are identical to K60/92. This grouping reflects the identity of residue 111; which is a glycine $(\mathrm{G})$ in the former and arginine $(\mathrm{R})$ in the latter strains, respectively. The other nucleotide changes (positions 309, 327, 335, 435) observed were all in isolate K15/97. 


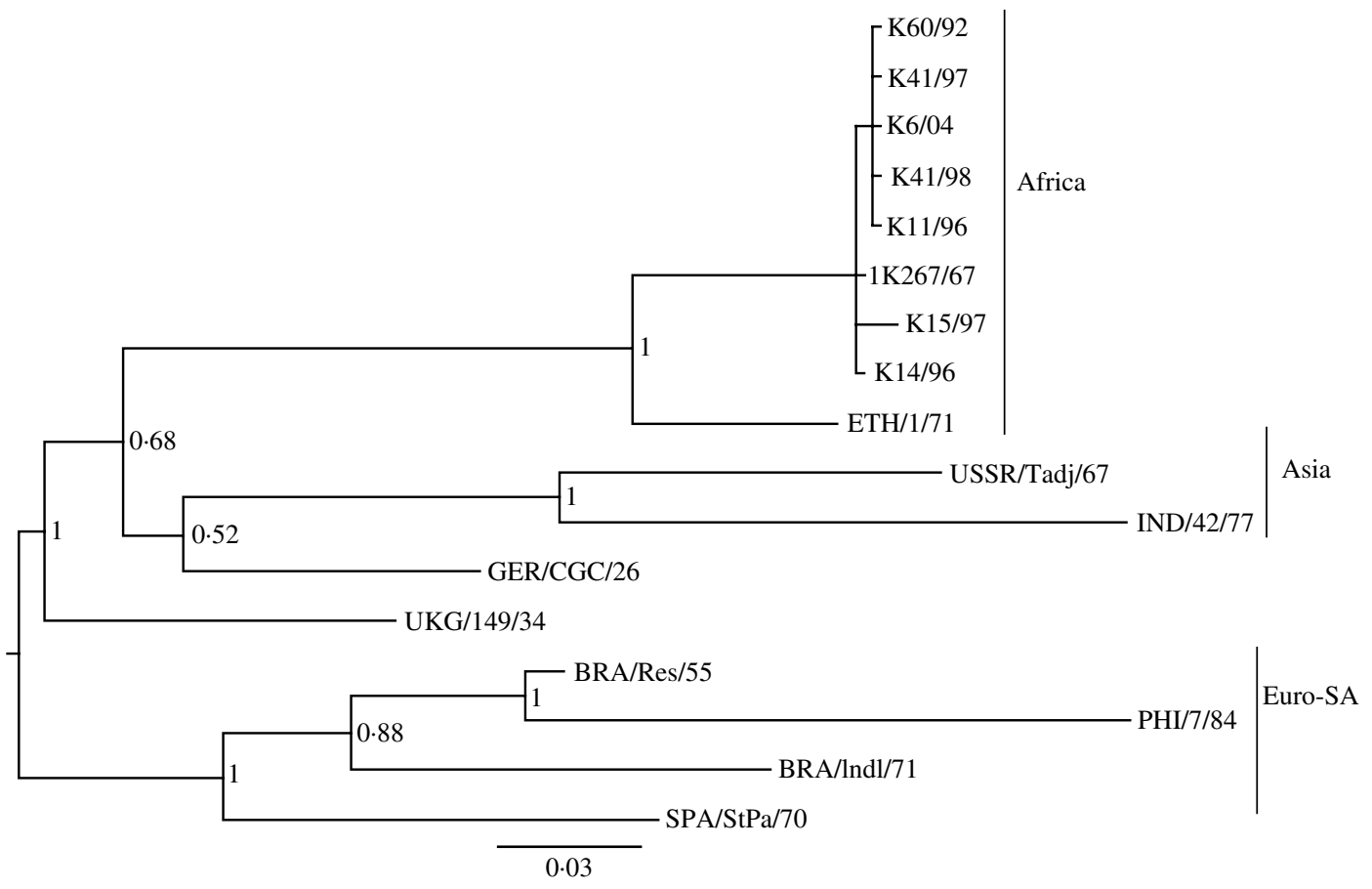

Fig. 4. Bayesian inference tree indicating the phylogenetic relationships between serotype $\mathrm{C}$ foot-and-mouth disease virus isolates. The three topotypes (Africa, Asia and Europe-South America) are indicated. Posterior probabilities $>50 \%$ for nodes are shown.

\section{DISCUSSION}

There has been very little change in the sequence of the VP1-coding region over a period of almost 40 years in the Kenyan type C FMDV isolates. Moreover, the vaccine strain (K267/67) that has been used to contain type $\mathrm{C}$ outbreaks is genetically closely related to each of the field strains. This lack of significant variation in viruses isolated over a long period of time is inconsistent with the expected levels of divergence given the rapid evolution of FMD viruses previously reported (e.g. [19-22]). FMDV serotypes are known to evolve rapidly resulting in a high lineage turnover [23]. Differences exist in the selection forces shaping the evolution of the serotypes with, for example, type C and SAT 3 major antigenic regions reported to be under no positive Darwinian selection when VP1coding sequences were analysed [24]. However, the low level of sequence divergence observed in this study is comparable to that observed in $C_{1}$ subtype strains from Europe, which showed very little change from 1953 to 1989 [4]. The absence of significant sequence divergence in type $\mathrm{C}$ strains has also been reported in India [25]. The apparently static evolution in the European subtype $C_{1}$ strains was attributed to multiple re-introductions of vaccine strains into the field through laboratory escapes or improperly inactivated vaccines. Many FMD outbreaks in Europe in the past have been attributed to improperly inactivated vaccines when formaldehyde was used [7]. For Kenya, available records at KEVEVAPI indicate that by the early 1980 s, formaldehyde had been abandoned and binary ethyleneimine (BEI) was in use for virus inactivation during vaccine production as recommended in Doel [26]. Type C vaccine has been distributed to the districts reporting type $\mathrm{C}$ outbreaks solely through the Directorate of Veterinary Services. The practice has been to apply ring vaccination to contain the outbreaks once reported and this applies to all the isolates in this study, i.e. vaccine was applied following the outbreak. Type $\mathrm{C}$ vaccine use peaked in the 1970s and early 1980s when the number of reported outbreaks was high (up to about 50 outbreaks a year affecting many districts) but then fell in the 1990s when only a few districts were affected. Kajiado district in the southern Rift Valley received the highest number of type C FMDV vaccine doses in 1973 ( $n=105800$ doses). From the 1990 s up to the last reported outbreak of type C in 2004, Baringo and Koibatek were the only districts that were supplied with type $\mathrm{C}$ vaccine to ring vaccinate and control respective outbreaks.

In a preliminary study, Roeder \& Knowles [5] reported a close relationship between some Kenyan 
type C strains and the vaccine strain K267/67 and suggested that this could be due to re-introductions of the vaccine strain into the field. They recommended the suspension of the use of the vaccine. Additionally, Kenyan field isolates of type $\mathrm{C}$ were observed to be antigenically closely related to the vaccine strain (Embakasi FMD laboratory records).

In the Kenyan situation, it is highly improbable that direct laboratory escape of the virus could be a source of these particular outbreaks as the concerned districts are geographically distant $(>200 \mathrm{~km})$ from Nairobi where the laboratory is located. Previous laboratory escapes of FMD viruses have been reported to occur near laboratories as was the case in the UK in 2007 [27]. Epidemiological information on the Kenyan outbreaks obtained by the veterinary department on the likely source and history of each outbreak also excluded possible escapes from the laboratory based on the fact that they occurred in districts far from Nairobi and no obvious transmission method, such as through laboratory personnel or visitors, could be found.

A possible explanation for these results is improperly inactivated vaccines as a probable source of field re-introductions which is consistent with the conclusions from Roeder \& Knowles [5] and similar reports in Europe [7], although the use of BEI early in the history of vaccine production at KEVEVAPI and the fact that vaccine was only used after the outbreak was reported makes this inference uncertain. High sequence similarity could also result from crosscontamination of the samples, for example during cell culture passage. Such a possibility is also unlikely in this study since the isolates were passaged at different times and incorporated negative controls of uninfected monolayer cells incubated in parallel and checked for lack of any cytopathic effects in strict adherence to good laboratory practice. The suggestion of improperly inactivated vaccines, although not unequivocally proven, highlights the importance of strengthening the availability of laboratory diagnostic capability at national FMD laboratories. However, to our knowledge, neither a definitive confirmation of vaccine-related outbreaks nor its possible epidemiological impact in Kenya has been reported. Although the conservative magnitude of change as well as the close similarity to the vaccine strain observed in this study for type $\mathrm{C}$ suggests that type $\mathrm{C}$ outbreaks are probably of vaccine origin, we found little evidence of vaccine strain re-introductions for the other serotypes in Kenya (unpublished results by the authors). Instead we observe a high rate of virus turnover for the other Kenyan FMDV serotypes as exemplified by as many as six (SAT 2), four (type A) and three (type $\mathrm{O}$ ) changes in vaccine strains over a similar period. This is despite the vaccine production procedure being the same for all the serotypes and the other serotype vaccines being used in much larger quantities and over a similar time period as the type $\mathrm{C}$ vaccine. Similarly, no outbreaks have been associated with vaccine inoculation during potency experiments. However, on the World Reference Laboratory for FMD website (http://www. wrlfmd.org/fmd_genotyping/africa/ken.htm) there appears to be evidence of field viruses being isolated sporadically which have very close genetic relationships to the other Kenyan vaccine strains.

The suggestion of probable vaccine strain reintroductions of this serotype in Kenya has implications for the control of the disease through vaccination. It may therefore be necessary to obtain definitive evidence for the possible linkage of the use of vaccines in the maintenance of serotype $\mathrm{C}$ FMD in Kenya. The association of vaccine usage with outbreaks poses a dilemma for the veterinary authorities in the country who have to decide on whether to continue maintaining expensive vaccine stocks for a seemingly disappearing serotype.

\section{ACKNOWLEDGEMENTS}

We sincerely thank the Director of Veterinary Services, Kenya, for providing the virus isolates used in the study and the Managing Director of KEVEVAPI, Dr Rufus Rumberia, for helpful comments and information on FMD vaccine production and use in Kenya. The assistance of Dr Sabenzia Wekesa, Teresa Kenduiywo, William Birgen and Eugene Arinaitwe is particularly appreciated. This work was supported by the Danish International Development Agency (DANIDA) under the Livestock-Wildlife Diseases in East Africa Project.

\section{DECLARATION OF INTEREST}

None.

\section{REFERENCES}

1. Grubman MJ, Baxt B. Foot-and-mouth disease. Clinical Microbiology Reviews 2004; 17: 465-493. 
2. Belsham GJ. Distinctive features of foot-and-mouth disease virus, a member of the picornavirus family; aspects of virus protein synthesis, protein processing and structure. Progress in Biophysics and Molecular Biology 1993; 60: 241-260.

3. Waldmann O, Trautwein K. Experimental studies about the plurality of the foot-and-mouth disease virus [in German]. Berliner Tierärztliche Wochenschrift 1926; 42: $569-571$.

4. Knowles NJ, Samuel AR. Molecular epidemiology of foot-and-mouth disease virus. Virus Research 2003; 91 : 65-80.

5. Roeder PL, Knowles NJ. Foot-and-mouth disease virus type $\mathrm{C}$ situation: the first target for eradication? In: The Global Control of FMD-Tools, Ideas and Ideals, 14-17 October 2008, Erice, Italy: FAO, Rome, 2009.

6. Bastos ADS, et al. The implications of virus diversity within the SAT 2 serotype for control of foot-andmouth disease in sub-Saharan Africa. Journal of General Virology 2003; 84: 1595-1606.

7. Beck E, Strohmaier K. Subtyping of European footand-mouth disease virus strains by nucleotide sequence determination. Journal of Virology 1987; 61: 16211629.

8. Knowles NJ, Samuel AR. Polymerase chain reaction amplification and cycle sequencing of the 1D gene of foot-and-mouth disease viruses In: Session of the research group of the standing technical committee of the European commission for the control of footand-mouth disease, 19-22 September 1994, Vienna, Austria: FAO, Rome, 1995.

9. Drummond AJ, et al. Geneious v. 4.6 (http://www. geneious.com/), 2009.

10. Nylander JAA. MrModeltest v. 2 (program distributed by the author). Evolutionary Biology Centre, Uppsala University, 2004.

11. Swofford DL. PAUP*. Phylogenetic Analysis Using Parsimony (*and other methods), 4th edn. Sunderland, Massachusetts: Sinauer Associates, 2003.

12. Hasegawa M, Kishino H, Yano T. Dating of the humanape splitting by a molecular clock of mitochondrial DNA. Journal of Molecular Evolution 1985; 22: 160-174.

13. Librado P, Rozas J. DnaSP v5: a software for comprehensive analysis of DNA polymorphism data. Bioinformatics 2009; 25: 1451-1452.
14. Nei M. Molecular Evolutionary Genetics. New York: Columbia University Press, 1987.

15. Tamura K, et al. MEGA4: Molecular Evolutionary Genetics Analysis (MEGA) software version 4.0. Molecular Biology and Evolution 2007; 24: 1596-1599.

16. Huelsenbeck JP, Ronquist F. MrBayes: Bayesian inference of phylogenetic trees. Bioinformatics 2001; 17: 754-755.

17. Neff S, et al. Foot-and-mouth disease virus virulent for cattle utilizes the integrin $\alpha \mathrm{v} \beta 3$ as its receptor. Journal of Virology 1998; 72: 3587-3594.

18. Jackson T, et al. The epithelial integrin $\alpha v \beta 6$ is a receptor for foot-and-mouth disease virus. Journal of Virology 2000; 74: 4949-4956.

19. Sobrino F, et al. Fixation of mutations in the viral genome during an outbreak of foot-and-mouth disease: heterogeneity and rate variations. Gene 1986; 50: 149-159.

20. Martinez MA, et al. Evolution of the capsid protein genes of foot-and-mouth disease virus: Antigenic variation without accumulation of amino acid substitutions over six decades. Journal of Virology 1992; 6: 3557 3565 .

21. Haydon DT, Samuel AR, Knowles NJ. The generation and persistence of genetic variation in foot-and-mouth disease virus. Preventive Veterinary Medicine 2001; 51: 111-124.

22. Tully DC, Fares MA. The tale of a modern animal plague: tracing the evolutionary history and determining the time-scale for foot and mouth disease virus. Virology 2008; 382: 250-256.

23. Mittal M, et al. Phylogeny, genome evolution, and antigenic variability among endemic foot-and-mouth disease virus type A isolates from India. Archives of Virology 2005; 150: 911-928.

24. Tully DC, Fares MA. Unravelling selection shifts among foot-and-mouth disease virus (FMDV) serotypes. Evolutionary Bioinformatics 2006; 2: 211-225.

25. Nagendrakumar SB, et al. Molecular characterization of foot-and-mouth disease virus type $\mathrm{C}$ of Indian origin. Journal of Clinical Microbiology 2005; 43: 966 969.

26. Doel TR. FMD vaccines. Virus Research 2003; 91 : 81-99.

27. Cottam EM, et al. Transmission pathways of foot-andmouth disease virus in the United Kingdom in 2007. PLoS Pathogens 2008; 4: 1-8. 